\title{
Protocorm Like Bodies (PLB) Anggrek Hasil Silangan Phalaenopsis gigantea $\times$ Phalaenopsis violacea pada Kombinasi Media dan ZPT
}

\author{
F1 of PLB orchid from Phalaenopsis gigantea $x$ Phalaenopsis violacea Hibridisation \\ Grow on Combination of Media and Plant growt Regulator
}

Sandra Arifin Aziz ${ }^{1 *}$, Dewi Sukma ${ }^{1}$, dan Nazi ${ }^{1}$

Diterima 14 Juli 2014/Disetujui 12 Agustus 2014

\begin{abstract}
The study was aimed to determine combination media and plant growt regulator to support growth of F1 of PLB orchid from Phalaenopsis gigantea $x$ Phalaenopsis violacea hibridisation, This research consist of two experiment. The first experiment use randomize complete block design with two factor i.e media and plant growth regulator $(P G R)$. The experiment used Knudson C $80 \%$ and NPK (18:18:18+EDTA) media, while the plant growth regulator used without PGR, coconut water, thidiazuron $(T D Z)+$ benziladenin $(B A)$. The second experiment was subculture in different media, Knudson C 80\% without PGR to Knudson C 80\% without PGR and NPK, NPK (20:20:20)+vitamin+myoinositol; NPK (18-18-18+EDTA) without PGR subculture to NPK (1818-18+EDTA) without PGR and NPK (20:20:20)+vitamin+myoinositol; NPK (18:18:18+EDTA) + TDZ 0.5 ppm+BA 0.5 ppm subculture to NPK $(18: 18: 18+E D T A)+T D Z 0.5$ ppm+BA 0.5 ppm and NPK (20:20:20)+ vitamin+myoinositol; KC 80\%+coconut water $100 \mathrm{ml}, \mathrm{KC} 80 \%+T D Z 0.5$ ppm+BA $0.5 \mathrm{ppm}$ and NPK (18:18:18+EDTA) + coconut water $100 \mathrm{ml}$ subculture to NPK (20:20:20)+ vitamin+myoinositol. The result showed that the best combination of media and plant growth regulator to proliferation was NPK (18:18:18+EDTA) without PGr media, and then subculture in the same media i.e NPK (20:20:20) +vitamin+ myoinositol.
\end{abstract}

Key words: Knudson C 80\%, Protocorm Like Bodies (PLB), orchid, thidiazuron,benziladenin

\section{ABSTRAK}

Penelitian ini bertujuan untuk mempelajari kombinasi media tanam dan zat pengatur tumbuh (ZPT) yang sesuai untuk mendukung pertumbuhan PLB anggrek hasil silangan antara Phalaenopsis gigantea $\times$ Phalaenopsis violacea. Penelitian terdiri atas 2 percobaan. Percobaan 1 menggunakan rancangan acak lengkap faktorial dengan 2 faktor, yaitu media tanam dan ZPT. Media yang digunakan adalah media Knudson C (KC) 80\% dan media NPK (18:18:18+EDTA), sedangkan ZPT yang dicobakan adalah tanpa penambahan ZPT, air kelapa, serta thidiazuron (TDZ) +benziladenin (BA). Percobaan 2 adalah subkultur pada media yang berbeda menggunakan rancangan acak lengkap yaitu, KC 80\% tanpa ZPT disubkultur ke KC 80\% tanpa ZPT dan NPK (20:20:20)+vitamin+ myoinositol; NPK (18-18-18+EDTA) tanpa ZPT disubkultur ke NPK (18-1818+EDTA) tanpa ZPT dan NPK (20:20:20)+vitamin+myoinosi tol; NPK (18:18:18+EDTA) +TDZ 0.5 ppm+BA 0.5 ppm disubkultur ke NPK (18:18:18+EDTA) +TDZ 0.5 ppm+BA 0.5 ppm dan NPK (20:20:20)+vitamin +myoinositol; KC 80\%+air kelapa $100 \mathrm{ml}$, KC 80\%+TDZ 0.5 ppm+BA 0.5 ppm dan NPK (18:18:18+EDTA) +air kelapa $100 \mathrm{ml}$ disubkultur ke NPK (20:20:20)+vitamin+ myoinositol. Hasil percobaan menunjukkan bahwa perlakuan media dan ZPT terbaik untuk proliferasi adalah media NPK (18:18:18+EDTA) tanpa penambahan ZPT, kemudian disubkultur pada media yang sama, atau media NPK (20:20:20) +vitamin + myoinositol.

Kata kunci: Knudson C 80\%, Protocorm Like Bodies (PLB), anggrek, thidiazuron, benziladenin

${ }^{1}$ Departemen Agronomi dan Hortikultura Institut Pertanian Bogor

Jln Meranti, Kampus Darmaga IPB, Bogor 16680

${ }^{*}$ Contact Person, email: sandraaziz@yahoo.com 


\section{PENDAHULUAN}

Induksi Protocorm Like Bodies (PLB) dengan menggunakan biji anggrek hasil silangan yang dikecambahkan merupakan salah satu cara dalam teknik kultur jaringan tanaman yang dilakukan untuk memperbanyak beberapa jenis anggrek Phalaenopsis. Beberapa prosedur kultur in vitro anggrek sudah dikembangkan untuk beberapa genus, diantaranya adalah Cymbidium, Vanda, Phaphiopedilum and Phalaenopsis (Arditti dan Ernst, 1993).

Hasil penelitian Bey et al. (2006) menunjukkan bahwa perlakuan tunggal air kelapa pada konsentrasi $250 \quad \mathrm{ml}^{-1}$ menghasilkan rata-rata persentase kecambah Phalaenopsis amabilis tertinggi, namun tidak menunjukkan perbedaan yang nyata dengan perlakuan 150 dan $200 \mathrm{ml} \mathrm{L}^{-1}$ air kelapa. Penggunaan pupuk majemuk NPK (6.5-2.615.8) dapat meningkatkan bobot PLB Phalaenopsis (Cardenas dan Wang, 1998). Media kultur jaringan dengan menggunakan pupuk NPK (20-20-20) ditambah $2 \mathrm{~g} \mathrm{~L}^{-1}$ pepton dan ditambah arang aktif optimal untuk perbanyakan PLB Phalaenopsis hibrida (Park et al., 2002) dan mampu memberikan respon yang positif pada perkecambahan biji anggrek Paraphalaenopsis serpentilingua (Puspitaningtyas et al., 2006).

Perlakuan pemberian thidiazuron (TDZ) efektif untuk menginduksi embriogenesis pada P. amabilis (Chen dan Chang, 2004). Latip et al. (2010) menunjukkan bahwa persentasi pertumbuhan PLB $P$. gigantea yang terbentuk dengan penambahan benziladenin (BAP) secara tunggal lebih rendah dibandingkan dengan penambahan thidiazuron (TDZ) pada konsentrasi yang sama.

Keberhasilan penggunaan metode kultur jaringan, terutama untuk induksi jumlah PLB ditentukan oleh kombinasi yang baik antara media kultur yang bertindak sebagai penyedia hara untuk pertumbuhan tanaman dan ZPT untuk menginduksi PLB, sehingga diperlukan penelitian untuk melakukan percobaan perlakuan media dengan penambahan ZPT untuk mendapatkan kombinasi media dan ZPT yang tepat untuk mendukung pertumbuhan PLB anggrek. Penelitian ini bertujuan untuk memperoleh kombinasi media tanam dan ZPT yang sesuai untuk mendukung pertumbuhan
PLB anggrek hasil silangan antara $P$. gigantea $\mathrm{x}$ P. violacea.

\section{BAHAN DAN METODE}

Penelitian dilakukan di Laboratorium Kultur Jaringan Departemen Agronomi dan Hortikultura, Fakultas Pertanian, Institut Pertanian Bogor pada bulan November 2013 sampai bulan Juni 2014. Bahan tanaman yang digunakan dalam penelitian adalah PLB hasil silangan $P$. gigantea $\times$ P violacea. Bahan lain yang digunakan adalah bahan-bahan untuk membuat media Knudson C (KC) $80 \%$, NPK (18-18-18-EDTA), NPK (20-20-20)+vitamin+ myoinositol, thidiazuron (TDZ) $0.5 \mathrm{ppm}$, benziladenin (BA) $0.5 \mathrm{ppm}$, nenas, pisang, dan air kelapa.

Percobaan terdiri atas 2 bagian. Percobaan 1 untuk menginduksi proliferasi PLB anggrek hasil silangan $P$. gigantea $\times P$. violacea, sedangkan untuk percobaan 2 subkultur untuk mendukung pertumbuhan PLB anggrek hasil silangan $P$. gigantea $\times P$. violacea.

\section{Percobaan 1}

Rancangan percobaan yang digunakan adalah rancangan acak lengkap (RAL) faktorial dengan 2 faktor yaitu jenis media dan zat pengatur tumbuh. Perlakuan yang dicobakan adalah penanaman PLB pada media perlakuan (Tabel 1), kemudian masing-masing unit percobaan ditanam masing-masing sebanyak 5 PLB dan diulang sebanyak 10 kali, sehingga terdapat 50 satuan percobaan.

\section{Percobaan 2}

Rancangan percobaan yang digunakan pada percobaan 2 adalah rancangan acak lengkap (RAL) dengan 1 faktor. Perlakuan subkultur pada percobaan 2 dijelaskan pada Tabel 1.

\section{Pengamatan}

Parameter yang diamati adalah persentase kontaminasi, persentase PLB hidup, persentase multiplikasi, persentase PLB berkalus, persentase PLB yang tidak berkalus dan tidak bermultiplikasi, jumlah daun dan jumlah akar. 
Tabel 1. Perlakuan media Percobaan 1 dan $2^{1}$

\begin{tabular}{ll}
\multicolumn{1}{c}{ Media pada Percobaan 1 } & \multicolumn{1}{c}{ Media Percobaan 2 } \\
\hline KC 80\% tanpa ZPT & KC 80\% tanpa ZPT \\
KC 80\% tanpa ZPT & NPK (20-20-20)+vitamin+myoinositol \\
NPK (18-18-18+EDTA) tanpa ZPT & NPK (18-18-18+EDTA) tanpa ZPT \\
NPK (18-18-18+EDTA) tanpa ZPT & NPK (20-20-20)+vitamin+myoinositol \\
NPK (18-18-18+EDTA) + TDZ 0.5 ppm + BA 0.5 ppm & NPK (18-18-18+EDTA) + TDZ 0.5 \\
& ppm + BA 0.5 ppm \\
NPK (18-18-18+EDTA) + TDZ 0.5 ppm + BA 0.5 ppm & NPK (20-20-20)+vitamin+myoinositol \\
KC 80\% + air kelapa 100 ml & NPK (20-20-20)+vitamin+myoinositol \\
KC 80\% + TDZ 0.5 ppm + BA 0.5 ppm & NPK (20-20-20)+vitamin+myoinositol \\
NPK 18-18-18+EDTA) + air kelapa 100 ml & NPK (20-20-20)+vitamin+myoinositol \\
\hline Keterangan: ${ }^{1}$ KC = media Knudson C, ZPT = zat pengatur tumbuh, TDZ = thidiazuron, BA = benziladenin, ppm = \\
$\quad$ part per million, EDTA = asam etilen diamin tetra asetat.
\end{tabular}

Persentase PLB hidup dihitung dari jumlah PLB yang berwarna hijau dibagi dengan jumlah PLB total dari masing-masing perlakuan. Persentase multiplikasi dihitung dari jumlah PLB yang masih berwarna hijau dan mengalami proliferasi dibagi dengan jumlah PLB total dari masing-masing perlakuan. Persentase kalus dihitung dari jumlah PLB yang mengalami pembentukan kalus dibagi dengan jumlah PLB total dari masingmasing perlakuan. Persentase PLB yang tidak bermultiplikasi dan tidak berkalus dihitung dari persentase PLB yang hidup pada masingmasing perlakuan dikurangi dengan persentase multiplikasi dan persentase kalus dari masingmasing perlakuan.

Jumlah daun dihitung dari jumlah daun yang terbentuk pada PLB, kemudian diambil rata-rata dari masing-masing perlakuan. Jumlah akar dihitung dari jumlah akar yang terbentuk pada PLB kemudian diambil ratarata dari masing-masing perlakuan. Pengamatan dilakukan setiap minggu selama 6 bulan. Data yang diperoleh pada percobaan 1 dan percobaan 2 dianalisis dengan menggunakan uji $\mathrm{F}$ untuk mengetahui pengaruh perlakuan media tanam dan ZPT. Pada hasil sidik ragam yang berpengaruh nyata dilakukan uji lanjut dengan Duncan Multiple Range Test (DMRT) pada selang kepercayaan 95\%.

\section{HASIL DAN PEMBAHASAN}

\section{Percobaan 1 Induksi Proliferasi PLB Persentase PLB Hidup}

Pertumbuhan eksplan dalam kultur in vitro sangat dipengaruhi oleh media kultur yang digunakan (George et al., 2007). Jenis media dan kandungan unsur hara yang digunakan sangat berpengaruh terhadap kecepatan pertumbuhan (Niedz dan Evans, 2007). Kesesuaian eksplan dan media yang digunakan menjadi faktor penting untuk menentukan keberhasilan kultur in vitro tanaman untuk berbagai tujuan (George et al., 2007).

Total persentase kontaminasi pada percobaan 1 adalah $7.5 \%$. PLB anggrek hasil silangan $P$. gigantea $\times P$. violacea yang hidup merupakan PLB yang masih berwarna hijau. PLB yang tidak terkontaminasi mulai menunjukkan pertumbuhan. Pertumbuhan PLB pada percobaan ini dapat dikelompokkan menjadi 3 yaitu PLB yang tumbuh dengan sangat lambat sehingga tidak mengalami multiplikasi ataupun berkalus, PLB yang mengalami multiplikasi, dan PLB yang berkalus.

Persentase PLB hidup untuk perlakuan ZPT nyata lebih tinggi dibandingkan dengan perlakuan penambahan air kelapa maupun TDZ+BA. Hasil analisis statistik menunjukkan bahwa perlakuan media KC $80 \%$ nyata lebih tinggi dibandingkan media NPK (18-1818+EDTA) dan perlakuan tanpa ZPT sangat nyata lebih tinggi dibandingkan dengan perlakuan penambahan air kelapa maupun 
TDZ+BA. Interaksi terjadi pada taraf media KC 80\% tanpa penambahan ZPT (Tabel 2). Hal tersebut diduga karena konsentrasi ZPT yang berasal dari air kelapa, TDZ dan BA terlalu tinggi, sehingga menekan pertumbuhan PLB anggrek. Hasil penelitian Niknejad (2009) menunjukkan bahwa induksi PLB berhasil dilakukan dengan menambah-kan BAP, TDZ, dan kinetin pada konsentrasi masing-masing $0.01,0.1$, dan $0.5 \mathrm{mg} \mathrm{L}^{-1}$.

\section{Persentase Multiplikasi dan Persentase Kalus}

Hasil percobaan pada PLB anggrek dengan kombinasi media dan ZPT menunjukkan bahwa perlakuan media NPK (18-18-18+EDTA) menghasilkan persentase multiplikasi sangat nyata lebih tinggi dibandingkan dengan media KC $80 \%$ (Tabel
3). Hasil analisis statistik menunjukkan bahwa jika dibandingkan dengan media $\mathrm{KC} 80 \%$, maka media NPK (18-18-18+EDTA) merupakan media terbaik untuk multiplikasi PLB. Perlakuan penambahan TDZ $0.5 \mathrm{ppm}$ dan BA $0.5 \mathrm{ppm}$ tidak berbeda nyata dengan perlakuan tanpa pemberian ZPT namun sangat nyata lebih tinggi dibandingkan dengan perlakuan penambahan air kelapa. Hal tersebut mengindikasikan bahwa untuk memperbanyak PLB anggrek silangan antara $P$. gigantea $\times P$. violacea tidak perlu dilakukan pada media yang ditambahkan ZPT. Selain itu, prosedur pembuatan media NPK (18-18-18+EDTA) lebih sederhana dibandingkan dengan pembuatan media KC $80 \%$. Penggunaan media NPK (18-18-18+EDTA) mampu menggantikan media KC $80 \%$ yang kurang ekonomis.

Tabel 2. Interaksi media dan ZPT terhadap persentase hidup PLB anggrek silangan $P$. gigantea $\times P$. violacea pada Umur $2 \mathrm{MST}^{1}$

\begin{tabular}{lcccc}
\hline \multirow{2}{*}{ Media } & \multicolumn{4}{c}{ ZPT } \\
\cline { 2 - 4 } & Tanpa ZPT & Air Kelapa & TDZ+BA & Rata-rata \\
\hline \multirow{2}{*}{ KC 80\% } & $76.6 \mathrm{a}$ & $45.7 \mathrm{~b}$ & $35.4 \mathrm{~b}$ & 52.6 \\
NPK (18-18-18+EDTA) & $41.1 \mathrm{~b}$ & $33.1 \mathrm{~b}$ & $38.9 \mathrm{~b}$ & 37.7 \\
Rata-rata & 58.9 & 39.4 & 37.1 & \\
Keterangan: & ${ }^{1}$ Angka-angka pada baris dan kolom yang sama yang diikuti oleh huruf yang sama menunjukkan hasil tidak berbeda \\
& nyata pada uji Duncan multiple range test (DMRT) pada selang kepercayaan 95\%. PLB= protocorm like bodies, \\
& ZPT= zat pengatur tumbuh, TDZ= thidiazuron, BA= benziladenin, MST= minggu setelah tanam, NPK= pupuk \\
& majemuk yang mengandung unsur N, P dan K. KC 80 \% = Knudson C, EDTA= asam etilen diamin tetra asetat.
\end{tabular}

Tabel 3. Rata-rata persentase PLB anggrek silangan $P$. gigantea $\times P$. violacea pada kombinasi media dan ZPT pada umur 10 MST

\begin{tabular}{|c|c|c|c|c|c|}
\hline Perlakuan & $\begin{array}{l}\text { Persentase } \\
\text { PLB Hidup }\end{array}$ & $\begin{array}{l}\text { Persentase } \\
\text { PLB Mati }\end{array}$ & $\begin{array}{l}\text { Persentase PLB } \\
\text { TM dan TB }\end{array}$ & $\begin{array}{c}\text { Persentase } \\
\text { Multiplikasi }^{1}\end{array}$ & $\begin{array}{l}\text { Persentase } \\
\text { Berkalus }\end{array}$ \\
\hline Media & \multicolumn{5}{|c|}{----------------------------------------(\%)------------------------------------ } \\
\hline Media KC $80 \%$ & $53.3 \mathrm{a}$ & 46.6 & 14.7 & $16.9 \mathrm{~b}$ & $21.7 \mathrm{a}$ \\
\hline $\begin{array}{l}\text { Media NPK (18-18- } \\
\text { 18+EDTA) }\end{array}$ & $54.67 \mathrm{a}$ & 45.3 & 12.0 & $25.7 \mathrm{a}$ & $16.9 \mathrm{a}$ \\
\hline Uji-F & tn & - & - & $* *$ & $\operatorname{tn}$ \\
\hline \multicolumn{6}{|l|}{ ZPT } \\
\hline Tanpa ZPT & $62.6 \mathrm{a}$ & 37.4 & 18.6 & $22.3 \mathrm{a}$ & $21.7 \mathrm{a}$ \\
\hline Air Kelapa & $45.4 \mathrm{~b}$ & 54.56 & 12.0 & $16.0 \mathrm{~b}$ & $17.4 \mathrm{a}$ \\
\hline TDZ+BA & $54.0 \mathrm{~b}$ & 46.0 & 9.4 & $25.7 \mathrm{a}$ & $18.9 \mathrm{a}$ \\
\hline $\mathrm{Uji}-\mathrm{F}$ & $* *$ & - & - & $* *$ & tn \\
\hline KK $(\%)$ & $8.8^{\mathrm{T} 1}$ & - & - & $7.4^{\mathrm{T} 1}$ & $7.6^{\mathrm{T} 1}$ \\
\hline $\begin{array}{r}\text { Keterangan: }{ }^{1} \text { Angka-angka } \\
\text { tidak berbeda } \\
\text { Like Bodies, } \\
\text { N, P dan K, } \\
\text { TM= tidak me } \\
\text { (DMRT) pada }\end{array}$ & $\begin{array}{l}\text { da kolom yang s } \\
\text { ata pada uji Dun } \\
\Gamma=\text { zat pengatur tu } \\
80 \%=\text { Knudsoi } \\
\text { alami multiplika }\end{array}$ & $\begin{array}{l}\text { a pada setiap } \\
\text { multiple ran } \\
\text { uh, MST }=\text { mi } \\
\text { TDZ }=\text { thidia } \\
\Gamma \mathrm{B}=\text { tidak berk }\end{array}$ & $\begin{array}{l}\text { kuan yang diikuti o } \\
\text { st (DMRT) pada sel } \\
\text { setelah tanam, NPK } \\
\mathrm{n}, \mathrm{BA}=\text { benzladenin } \\
\mathrm{t} \mathrm{n}=\text { tidak berbeda } \mathrm{n}\end{array}$ & $\begin{array}{l}\text { huruf yang sama } \\
\text { kepercayaan } 95 \% \\
\text { upuk majemuk yar } \\
\text { TA }=\text { asam etilen } \\
\text { pada uji Duncan } \\
\text { nsformasi } \sqrt{x+1} \text {. }\end{array}$ & $\begin{array}{l}\text { lunjukkan hasil } \\
\mathrm{B}=\text { Protocorm } \\
\text { erdiri dari unsur } \\
\text { min tetra asetat, } \\
\text { ltiple range test }\end{array}$ \\
\hline
\end{tabular}




\section{Jumlah Daun, Jumlah Akar dan Persentase Planlet yang Terbentuk}

Hasil analisis statistik menunjukkan bahwa media yang terbaik untuk pembentukan daun adalah media NPK (18-18-18+EDTA) (Tabel 5). Daun yang tumbuh pada PLB merupakan diferensiasi lebih lanjut ketika PLB sudah bertunas. Jumlah daun yang muncul pada PLB menunjukkan jumlah tunas yang terbentuk. PLB mempunyai titik tumbuh pada bagian atas tunas yang akan menjadi daun. Hal tersebut disebabkan karena proporsi nitrogen pada media NPK (18-18-18+EDTA) lebih tinggi dibandingkan pada media KC $80 \%$. Menurut Shintiavira et al. (2012) proporsi nitrogen dan fosfor sangat me-nentukan untuk pembentukan daun ataupun akar. Matulata (2003) menyatakan bahwa pemberian nitrogen dapat menginduksi pembentukan sitokinin pada tanaman. Sitokinin pada tanaman berfungsi untuk menginduksi tunas. Sukma (2010) menyatakan bahwa Pengaruh waktu dan frekuensi aplikasi pupuk daun memberikan pengaruh terhadap panjang daun pertama (daun termuda) pada anggrek Dendrobium.

Pembentukan akar dimulai dengan adanya proses metabolisme karbohidrat yang akan mendorong terbentuknya sel-sel baru. Akar merupakan bagian tanaman yang berfungsi untuk menyerap hara yang ada pada media kultur. Salah satu unsur yang dibutuhkan untuk membentuk akar adalah fosfor (Supari, 1999). Kandungan unsur N, P dan K pada media KC 80\%, NPK (18-18-18+EDTA) dan NPK (20-20-20) dapat dilihat pada Tabel 4.

Hasil analisis statistik menunjukkan bahwa media NPK (18-18-18+EDTA) merupakan media yang terbaik untuk pembentukan akar. Perlakuan tanpa pemberian ZPT merupakan perlakuan terbaik untuk meningkatkan pembentukan akar untuk PLB anggrek silangan $P$. gigantean $\times$ P.violacea. Media NPK (18-1818+EDTA) dan media NPK (20-20-20) mempunyai konsentrasi nitrogen yang lebih tinggi dibandingkan dengan konsentrasi fosfor, sehingga pertumbuhan PLB cenderung membentuk daun. Shintiavira et al. (2012) menyatakan bahwa pada kultur in vitro krisan, konsentrasi nitrogen yang lebih besar dibandingkan dengan konsentrasi fosfor, akan menyebabkan PLB cenderung membentuk daun. Sebaliknya jika konsentrasi fosfor lebih tinggi dibandingkan dengan konsentrasi nitrogen, maka pertumbuhan PLB cenderung membentuk akar. Perlakuan tanpa pemberian ZPT sangat nyata lebih tinggi dan lebih baik dibandingkan dengan perlakuan dengan penambahan air kelapa atau TDZ+BA. Hal tersebut diduga karena konsentrasi ZPT yang diberikan terlalu tinggi sehingga menekan pertumbuhan akar.

Planlet merupakan tanaman tanaman yang sudah siap untuk dilakukan aklimatisasi. Planlet yang terbentuk pada percobaan ini merupakan planlet yang sudah mempunyai minimal 2 daun dan 1 akar. Hasil analisis statistik menunjukkan bahwa persentase terbentuknya planlet pada media NPK (18-1818+EDTA) sangat nyata lebih tinggi dan lebih baik dibandingkan dengan media KC $80 \%$. Persentase terbentuknya planlet pada perlakuan tanpa penambahan ZPT nyata lebih tinggi dan lebih baik dibandingkan dengan perlakuan penambahan ZPT berupa air kelapa atau TDZ+BA (Tabel 5).

\section{Percobaan 2 Pertumbuhan PLB Persentase PLB Hidup}

Persentase PLB hidup pada percobaan 2 menunjukkan peningkatan dibandingkan dengan persentase PLB hidup pada percobaan 1. Tabel 6 menunjukkan rata-rata persentase hidup PLB pada 5 MST. Perlakuan terbaik untuk mempertahankan PLB tetap hidup adalah perlakuan $\mathrm{KC} \quad 80 \%$ tanpa ZPT disubkultur ke KC $80 \%$ tanpa ZPT, KC $80 \%$ tanpa ZPT disubkultur ke NPK (20-2020)+vitamin+myoinositol, NPK (18-1818+EDTA) tanpa ZPT disubkultur ke NPK (18-18-18+EDTA) tanpa ZPT, NPK (18-1818+EDTA) tanpa ZPT disubkultur ke NPK (20-20-20)+vitamin+myoinositol, dan NPK (18-18-18+EDTA) + TDZ $0.5 \mathrm{ppm}+$ BA 0.5 ppm disubkultur ke NPK (20-2020)+vitamin+myoinositol (Tabel 6).

MacDonald (2000) menyatakan bahwa untuk tumbuh dengan baik, tanaman memerlukan beberapa vitamin sebagai koenzim. Asam amino dapat membantu differensiasi jaringan dan digunakan dalam sintesis protein, sedangkan vitamin berguna untuk pertumbuhan tanaman khususnya pada jaringan aktif. Beberapa vitamin juga berperan sebagai kofaktor enzim agar enzim dapat aktif bekerja. 
J. Hort. Indonesia 5(2):118-127. Agustus 2014.

Tabel 4. Kandungan unsur N, P dan K pada media KC 80\%, NPK (18-18-18+EDTA) dan NPK (20-20-20)

\begin{tabular}{|c|c|c|c|}
\hline \multirow{2}{*}{ Unsur } & \multicolumn{3}{|c|}{ Media } \\
\hline & $\mathrm{KC} 80 \%$ & NPK (18-18-18+EDTA) & NPK (20-20-20) \\
\hline & \multicolumn{3}{|c|}{ 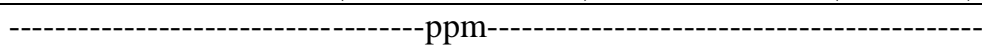 } \\
\hline Nitrogen & 256.8 & 271.4 & 400.0 \\
\hline Fosfor & 46.0 & 155.7 & 200.0 \\
\hline Kalium & 164.0 & 268.5 & 281.5 \\
\hline
\end{tabular}

Tabel 5. Rata-rata jumlah akar, jumlah daun dan persentase planlet anggrek silangan $P$. gigantea $\times$ $P$. violacea yang terbentuk pada umur 10 MST

\begin{tabular}{|c|c|c|c|}
\hline Perlakuan & Jumlah Akar & Jumlah Daun & Planlet(\%) \\
\hline \multicolumn{4}{|l|}{ Media } \\
\hline Media KC $80 \%$ & $0.1 \mathrm{~b}$ & $0.7 \mathrm{~b}$ & $4.9 \mathrm{~b}$ \\
\hline Media NPK (18-18-18+EDTA) & $0.2 \mathrm{a}$ & $0.9 \mathrm{a}$ & $13.9 \mathrm{a}$ \\
\hline Uji-F & $* *$ & $* *$ & $* *$ \\
\hline \multicolumn{4}{|l|}{ ZPT } \\
\hline Tanpa ZPT & $0.2 \mathrm{a}$ & $0.8 \mathrm{a}$ & $13.1 \mathrm{a}$ \\
\hline Air Kelapa & $0.1 \mathrm{~b}$ & $0.9 \mathrm{a}$ & $7.4 \mathrm{~b}$ \\
\hline TDZ+BA & $0.1 \mathrm{~b}$ & $0.8 \mathrm{a}$ & $7.7 \mathrm{~b}$ \\
\hline Uji-F & $* *$ & tn & $*$ \\
\hline KK (\%) & $6.9^{\mathrm{T1}}$ & $8.3^{\mathrm{T} 1}$ & $5.6^{\mathrm{T} 1}$ \\
\hline
\end{tabular}

Tabel 6. Rata-rata persen hidup PLB anggrek silangan $P$. gigantea $\times$ P. violacea pada percobaan 2 umur 5 MST

\begin{tabular}{|c|c|c|c|}
\hline No. & Perlakuan & PLB Hidup & PLB Mati \\
\hline & & \multirow{2}{*}{\multicolumn{2}{|c|}{ 64.0ab 36.0}} \\
\hline 1 & KC 80\% tanpa ZPT disubkultur ke KC $80 \%$ tanpa ZPT & & \\
\hline 2 & $\begin{array}{l}\text { KC } 80 \% \text { tanpa ZPT disubkultur ke NPK }(20-20- \\
\text { 20)+vitamin+myoinositol }\end{array}$ & $61.3 \mathrm{ab}$ & 38.7 \\
\hline 3 & $\begin{array}{l}\text { NPK (18-18-18+EDTA) tanpa ZPT disubkultur ke NPK (18-18- } \\
\text { 18+EDTA) tanpa ZPT }\end{array}$ & $66.7 \mathrm{ab}$ & 33.3 \\
\hline 4 & $\begin{array}{l}\text { NPK (18-18-18+EDTA) tanpa ZPT disubkultur ke NPK (20-20- } \\
\text { 20)+vitamin+myoinositol }\end{array}$ & $76.0 \mathrm{a}$ & 24.0 \\
\hline 5 & $\begin{array}{l}\text { NPK (18-18-18+EDTA) + TDZ } 0.5 \text { ppm + BA } 0.5 \text { ppm disubkultur } \\
\text { ke NPK (18-18-18+EDTA) + TDZ } 0.5 \text { ppm + BA } 0.5 \text { ppm }\end{array}$ & $53.3 \mathrm{bc}$ & 46.7 \\
\hline 6 & $\begin{array}{l}\text { NPK (18-18-18+EDTA) + TDZ } 0.5 \mathrm{ppm}+\text { BA } 0.5 \mathrm{ppm} \\
\text { disubkultur ke NPK (20-20-20)+vitamin+myoinositol }\end{array}$ & $62.7 \mathrm{ab}$ & 37.3 \\
\hline 7 & $\begin{array}{l}\text { KC } 80 \% \text { + Air Kelapa } 100 \mathrm{ml} \text { disubkultur ke NPK (20-20- } \\
\text { 20)+vitamin+myoinositol }\end{array}$ & $50.7 \mathrm{bc}$ & 49.3 \\
\hline 8 & $\begin{array}{l}\text { KC } 80 \%+\text { TDZ } 0.5 \text { ppm + BA } 0.5 \text { ppm disubkultur ke NPK (20- } \\
\text { 20-20)+vitamin+myoinositol }\end{array}$ & $46.7 \mathrm{bc}$ & 53.3 \\
\hline 9 & $\begin{array}{l}\text { NPK (18-18-18+EDTA) + Air Kelapa } 100 \mathrm{ml} \text { disubkultur ke } \\
\text { NPK (20-20-20)+vitamin+myoinositol }\end{array}$ & $40.0 \mathrm{c}$ & 60.0 \\
\hline & Uji-F & $* *$ & - \\
\hline & $\mathrm{KK}(\%)$ & $8.2^{\mathrm{T} 1}$ & - \\
\hline
\end{tabular}

Keterangan: ${ }^{1}$ Angka-angka pada kolom yang sama yang diikuti oleh huruf yang sama menunjukkan hasil tidak berbeda nyata pada uji Duncan multiple range test (DMRT) pada selang kepercayaan $95 \%$. **=sangat berbeda nyata pada uji DMRT selang kepercayaan $95 \%, \mathrm{KK}=$ koefisien keragaman, $^{(\mathrm{T} 1)}=$ hasil transformasi $\sqrt{x+1}$. 


\section{Persentase Multiplikasi dan Persentase Kalus}

Gejala yang terjadi pada PLBs yang sudah disubkutur adalah pembesaran ukuran PLB. Tabel 7 menunjukkan rata-rata persentase mutiplikasi, persentase kalus, dan persentase PLB yang tidak tumbuh. Hasil analisis statistik menunjukkan bahwa semua perlakuan pada percobaan 2 sangat mempengaruhi persentase multiplikasi PLB anggrek silangan $P$. gigantea $\times$ P.violacea .

Perlakuan subkultur terbaik pada media KC $80 \%$ tanpa ZPT disubkultur ke NPK (2020-20)+vitamin+myoinositol, media NPK (1818-18+EDTA) tanpa ZPT disubkultur ke NPK (18-18-18+EDTA) tanpa ZPT, media NPK (18-18-18+EDTA) tanpa penambahan ZPT yang disubkultur ke media NPK (20-2020)+vitamin+myoinositol, media NPK (18-18-
18+EDTA) + TDZ $0.5 \mathrm{ppm}+$ BA $0.5 \mathrm{ppm}$ disubkultur ke NPK (20-20-20)+ zvitamin+ myoinositol, media KC 80\% + Air Kelapa 100 ml disubkultur ke NPK (20-20-20)+vitamin+ myoinositol dan media NPK (18-18-18+ EDTA + Air Kelapa $100 \mathrm{ml}$ disubkultur ke NPK (20-20-20)+vitamin+ myoinositol.

Hal tersebut diduga karena kandungan hara yang ada pada media NPK (20-20-20) lebih tinggi, sehingga mampu mendukung pertumbuhan PLB. Puspitaningtyas et al. (2006) menjelaskan bahwa penggunaan media NPK (20-20-20) $2 \mathrm{~g} \mathrm{~L}^{-1}$ perkecambahan biji anggrek Paraphalaenopsis serpentilingua. Sari et al. (2009) menjelaskan bahwa media NPK (32-10-10) $2 \mathrm{~g} \mathrm{~L}^{-1}$ yang ditambah pepton memberikan hasil terbaik untuk perkecambahan biji anggrek Dendrobium sp.

Tabel 7. Rata-rata persentase multiplikasi, persentase kalus, dan persentase PLB yang tidak membentuk kalus dan multiplikasi pada umur $5 \mathrm{MST}^{1}$

\begin{tabular}{|c|c|c|c|c|}
\hline No. & Perlakuan & $\begin{array}{c}\text { Persentase } \\
\text { Multiplikasi }\end{array}$ & $\begin{array}{l}\text { Persentase } \\
\text { Kalus }\end{array}$ & $\begin{array}{l}\text { Persentase PLB } \\
\text { TM dan TB } \\
\end{array}$ \\
\hline & & \multicolumn{3}{|c|}{ 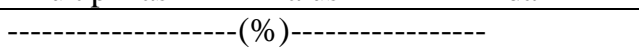 } \\
\hline 1 & $\begin{array}{l}\text { KC } 80 \% \text { tanpa ZPT disubkultur ke KC } 80 \% \\
\text { tanpa ZPT }\end{array}$ & $14.7 \mathrm{c}$ & $20.0 \mathrm{a}$ & 29.3 \\
\hline 2 & $\begin{array}{l}\text { KC 80\% tanpa ZPT disubkultur ke NPK (20- } \\
\text { 20-20)+vitamin+myoinositol }\end{array}$ & $33.3 \mathrm{ab}$ & $17.3 \mathrm{a}$ & 10.7 \\
\hline 3 & $\begin{array}{l}\text { NPK (18-18-18+EDTA) tanpa ZPT disubkultur } \\
\text { ke NPK (18-18-18+EDTA) tanpa ZPT }\end{array}$ & $22.7 \mathrm{abc}$ & $4.0 \mathrm{c}$ & 40.0 \\
\hline 4 & $\begin{array}{l}\text { NPK (18-18-18+EDTA) tanpa ZPT disubkultur } \\
\text { ke NPK (20-20-20)+vitamin+myoinositol }\end{array}$ & $36.0 \mathrm{a}$ & $2.7 \mathrm{c}$ & 37.3 \\
\hline 5 & $\begin{array}{l}\text { NPK (18-18-18+EDTA })+ \text { TDZ } 0.5 \mathrm{ppm}+\mathrm{BA} \\
0.5 \text { ppm disubkultur ke NPK }(18-18- \\
\text { 18+EDTA })+ \text { TDZ } 0.5 \mathrm{ppm}+\mathrm{BA} 0.5 \mathrm{ppm}\end{array}$ & $22.7 \mathrm{bc}$ & $2.7 \mathrm{c}$ & 27.9 \\
\hline 6 & $\begin{array}{l}\text { NPK (18-18-18+EDTA) + TDZ } 0.5 \text { ppm + BA } \\
0.5 \text { ppm disubkultur ke NPK }(20-20- \\
\text { 20)+vitamin+myoinositol }\end{array}$ & $33.3 \mathrm{ab}$ & $5.3 \mathrm{bc}$ & 24.0 \\
\hline 7 & $\begin{array}{l}\text { KC } 80 \% \text { + Air Kelapa } 100 \text { ml disubkultur ke } \\
\text { NPK }(20-20-20)+\text { vitamin+myoinositol }\end{array}$ & $18.7 \mathrm{abc}$ & $13.3 \mathrm{ab}$ & 18.7 \\
\hline 8 & $\begin{array}{l}\text { KC } 80 \%+\text { TDZ } 0.5 \text { ppm + BA } 0.5 \text { ppm } \\
\text { disubkultur ke NPK (20-20- } \\
\text { 20)+vitamin+myoinositol }\end{array}$ & $17.3 \mathrm{bc}$ & $14.7 \mathrm{a}$ & 14.7 \\
\hline \multirow[t]{3}{*}{9} & $\begin{array}{l}\text { NPK (18-18-18+EDTA) + Air Kelapa } 100 \mathrm{ml} \\
\text { disubkultur ke NPK (20-20- } \\
\text { 20)+vitamin+myoinositol }\end{array}$ & $24.0 \mathrm{abc}$ & $4.0 \mathrm{c}$ & 12.0 \\
\hline & Uji-F & $*$ & ** & - \\
\hline & $\mathrm{KK}(\%)$ & $8.3^{\mathrm{T} 1}$ & $5.1^{\mathrm{T} 1}$ & - \\
\hline & $\begin{array}{l}\text { an: }{ }^{1} \text { Angka-angka pada kolom yang sama yang diiku } \\
\text { berbeda nyata pada uji Duncan multiple range test } \\
\text { majemuk yang mengandung unsur } \mathrm{N}, \mathrm{P} \text { dan } \mathrm{K} . \mathrm{KC} \\
\text { benziladenin, } \mathrm{EDTA}=\text { asam etilena diamina tetraas } \\
\text { multiplikasi, TB }=\text { tidak berkalus, * =berbeda nyata } \\
\text { berbeda nyata pada uji DMRT selang kepercay } \\
\text { transformasi } \sqrt{x+1}\end{array}$ & $\begin{array}{l}\text { oleh huruf y } \\
\text { MRT) pada sel } \\
0 \%=\text { Knudso } \\
\text { at, ppm= part } \\
\text { da uji DMRT } \\
\text { an } 95 \% \text {, KK }\end{array}$ & $\begin{array}{l}\text { sama ment } \\
\text { kepercayaa } \\
80 \% \text {, TD2 } \\
\text { r million, TI } \\
\text { ang kepercay } \\
\text { koefisien ke }\end{array}$ & $\begin{array}{l}\text { ukkan hasil tidak } \\
5 \% . \mathrm{NPK}=\text { pupuk } \\
\text { thidiazuron, BA= } \\
=\text { tidak mengalami } \\
\text { n } 95 \%, * *=\text { sangat } \\
\text { gaman }\end{array}$ \\
\hline
\end{tabular}




\section{Jumlah Daun dan Jumlah Akar}

Rata-rata jumlah daun yang tumbuh pada percobaan 2 mengalami peningkatan sampai 5 MST. (Tabel 8). Hasil analisis statistik menunjukkan bahwa media NPK (18-1818+EDTA) tanpa ZPT disubkultur ke media NPK (20-20-20)+vitamin+myoinositol, NPK (18-18-18+ EDTA) tanpa ZPT disubkultur keNPK (18-18-18+EDTA), NPK (18-1818+EDTA) + TDZ $0.5 \mathrm{ppm}+$ BA $0.5 \mathrm{ppm}$ disubkultur ke NPK (18-18-18+EDTA) + TDZ $0.5 \mathrm{ppm}+\mathrm{BA} 0.5 \mathrm{ppm}$, NPK (18-18$18+$ EDTA $)+$ TDZ $0.5 \mathrm{ppm}+$ BA $0.5 \mathrm{ppm}$ disubkultur ke NPK (20-20-20)+vitamin+ myo inositol sangat nyata lebih tinggi dibandingkan dengan perlakuan lainnya.

Tabel 8 menunjukkan rata-rata jumlah akar yang tumbuh pada PLB anggrek silangan $P$. gigantea $\times P$. violacea. Hasil analisis statistik menunjukkan bahwa tanpa penambahan ZPT jumlah akar pada media NPK (18-18-18+ EDTA) disubkultur ke NPK (18-18-18+ EDTA) dan media NPK (18-18-18+EDTA) disubkultur ke NPK (20-20-20)+vitamin+ myoinositol sangat nyata lebih tinggi dibandingkan dengan perlakuan lainnya dan merupakan media terbaik untuk mendukung petumbuhan akar PLB anggrek silangan $P$. gigantea $\times$ P. violacea (Tabel 8).

Persentase planlet yang terbentuk pada perlakuan media NPK (18-18-18+EDTA) tanpa ZPT disubkultur ke NPK (20-20-20)+vitamin+ myoinositol, NPK (18-18-18+EDTA) tanpa ZPT disubkultur ke NPK (18-18-18+EDTA) tanpa ZPT dan NPK (18-18-18+EDTA) + TDZ $0.5 \mathrm{ppm}+\mathrm{BA} 0.5 \mathrm{ppm}$ disubkultur ke NPK (18-18-18+EDTA) + TDZ 0.5 ppm + BA $0.5 \mathrm{ppm}$ nyata lebih tinggi dibandingkan dengan perlakuan lainnya.

Tabel 8. Rata-rata jumlah daun dan jumlah akar PLB Anggrek silangan P. gigantea $\times P$. violacea

\begin{tabular}{|c|c|c|c|c|}
\hline \multirow[b]{2}{*}{ No. } & \multirow[b]{2}{*}{ Perlakuan } & \multicolumn{3}{|c|}{ 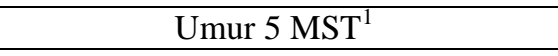 } \\
\hline & & $\begin{array}{c}\text { Jumlah } \\
\text { Akar }\end{array}$ & $\begin{array}{c}\text { Jumlah } \\
\text { Daun }\end{array}$ & Planlet(\%) \\
\hline 1 & KC 80\% tanpa ZPT disubkultur ke KC 80\% tanpa ZPT & $0.2 \mathrm{~b}$ & $0.8 \mathrm{bc}$ & $13.3 \mathrm{cde}$ \\
\hline 2 & $\begin{array}{l}\text { KC 80\% tanpa ZPT disubkultur ke NPK (20-20- } \\
\text { 20)+vitamin+myoinositol }\end{array}$ & $0.2 b$ & $0.7 b c$ & $10.7 \mathrm{de}$ \\
\hline 3 & $\begin{array}{l}\text { NPK (18-18-18+EDTA) tanpa ZPT disubkultur ke } \\
\text { NPK (18-18-18+EDTA) tanpa ZPT }\end{array}$ & $0.5 \mathrm{a}$ & $0.9 \mathrm{ab}$ & $29.3 \mathrm{ab}$ \\
\hline 4 & $\begin{array}{l}\text { NPK (18-18-18+EDTA) tanpa ZPT disubkultur ke } \\
\text { NPK (20-20-20)+vitamin+myoinositol }\end{array}$ & $0.6 \mathrm{a}$ & $1.2 \mathrm{a}$ & $34.7 \mathrm{a}$ \\
\hline 5 & $\begin{array}{l}\text { NPK }(18-18-18+E D T A)+\text { TDZ } 0.5 \mathrm{ppm}+\mathrm{BA} 0.5 \\
\text { ppm disubkultur ke NPK }(18-18-18+\mathrm{EDTA})+\mathrm{TDZ} \\
0.5 \mathrm{ppm}+\mathrm{BA} 0.5 \mathrm{ppm}\end{array}$ & $0.3 b$ & $0.9 \mathrm{ab}$ & $22.7 \mathrm{abc}$ \\
\hline 6 & $\begin{array}{l}\text { NPK (18-18-18+EDTA) + TDZ } 0.5 \text { ppm + BA } 0.5 \\
\text { ppm disubkultur ke NPK (20-20- } \\
\text { 20)+vitamin+myoinositol }\end{array}$ & $0.3 b$ & $0.9 \mathrm{ab}$ & $18.7 \mathrm{bcd}$ \\
\hline 7 & $\begin{array}{l}\text { KC } 80 \% \text { + Air Kelapa } 100 \mathrm{ml} \text { disubkultur ke NPK } \\
(20-20-20)+\text { vitamin+myoinositol }\end{array}$ & $0.2 \mathrm{~b}$ & $0.8 b c$ & $6.7 \mathrm{de}$ \\
\hline 8 & $\begin{array}{l}\text { KC } 80 \%+\text { TDZ } 0.5 \text { ppm + BA } 0.5 \text { ppm disubkultur } \\
\text { ke NPK (20-20-20)+vitamin+myoinositol }\end{array}$ & $0.1 \mathrm{~b}$ & $0.5 \mathrm{c}$ & $4.0 \mathrm{e}$ \\
\hline 9 & $\begin{array}{l}\text { NPK (18-18-18+EDTA) + Air Kelapa } 100 \mathrm{ml} \\
\text { disubkultur ke NPK (20-20- } \\
\text { 20)+vitamin+myoinositol }\end{array}$ & $0.3 b$ & $0.7 b c$ & $12.0 \mathrm{cde}$ \\
\hline & Uji-F & $* *$ & ** & ** \\
\hline & $\mathrm{KK}(\%)$ & $9.7^{\mathrm{T1}}$ & $8.3^{\mathrm{T} 2}$ & $7.1^{\mathrm{T} 1}$ \\
\hline
\end{tabular}

Keterangan: ${ }^{1}$ Angka-angka pada kolom yang sama yang diikuti oleh huruf yang sama menunjukkan hasil tidak berbeda nyata pada uji Duncan multiple range test (DMRT) pada selang kepercayaan $95 \%$. NPK= pupuk majemuk yang mengandung unsur $\mathrm{N}$, $\mathrm{P}$ dan $\mathrm{K}$. KC $80 \%=$ Knudson $\mathrm{C}$, TDZ= thidiazuron, $\mathrm{BA}=$ benziladenin, $\mathrm{EDTA}=$ asam etilena diamina tetraasetat, $\mathrm{ppm}=$ part per million, $\mathrm{tn}=$ tidak berbeda nyata pada uji Duncan multiple range test (DMRT) pada selang kepercayaan $95 \%$, *=berbeda nyata pada uji DMRT selang kepercayaan $95 \%, * *=$ sangat berbeda nyata pada uji DMRT selang kepercayaan $95 \%$, $\mathrm{KK}=$ koefisien keragaman, ${ }^{\mathrm{T} 1)}=$ hasil transformasi $\sqrt{x+1}$. 
Shintiavira et al. (2012) menyatakan bahwa pemberian media NPK (20-20-20) merupakan pengganti media MS terbaik untuk mendukung pertumbuhan eksplan krisan. Pada umur 8 MST media tersebut mampu memberikan rata-rata terbaik untuk jumlah daun, jumlah buku, jumlah akar, panjang akar, dan berat basah planlet krisan. Rachmatullah (2009) menyatakan bahwa media NPK (20-2020) $1 \mathrm{~g} \mathrm{~L}^{-1}+$ vitamin memperlihatkan hasil yang baik terhadap jumlah daun (4.95 helai) dan panjang daun $(16.75 \mathrm{~mm})$, dan mem perlihatkan hasil paling baik terhadap tinggi tunas $(8.28 \mathrm{~mm})$, lebar daun $(4.88 \mathrm{~mm})$ dan panjang akar $(44.98 \mathrm{~mm})$ pada PLB Dendrobium sp.

\section{KESIMPULAN}

Media dan ZPT terbaik untuk proliferasi adalah media NPK (18:18:18 + EDTA) tanpa penambahan ZPT, kemudian disubkultur pada media yang sama, atau media NPK (20:20: 20)+vitamin + myoinositol.

\section{UCAPAN TERIMA KASIH}

Ucapan terima kasih disampaikan kepada Kementrian Pendidikan dan Kebudayaan atas dana penelitian Desentralisasi 2014.

\section{DAFTAR PUSTAKA}

Arditti, J., R. Ernst. 1993. Phalaenopsis: Micropropagation of Orchids. John Wiley \& Sons, Inc. New York, Chichester, Brisbane, Toronto, Singapore. p. 467-520.

Bey, Y., Syafii, Sutrisna. 2006. Pengaruh pemberia giberelin (GA3) dan air kelapa terhadap perkecambahan biji anggrek bulan (Phalaenopsis amabilis BL.) secara in-vitro. J. Biogenesis. 2: 41-46.

Cardenas, E.C., Y.T. Wang. 1998. The effect of micronutrients and GA on the growth of Phalaenopsis in vitro. Subtropic Plant Sci. Vol. 50.
Chen, J.T, W.C. Chang. 2004. Induction of repetitive embryogenesis from seed derived protocorms of Phalaenopsis amabilis var. Formosa Shimadzu. In Vitro Cell Dev. Biol. 40: 290-293.

Djaafarer, R. 2002. Phalaenopsis Spesies. Jenis dan potensi untuk silangan. Penebar Swadaya. hlm.1-12. Jakarta.

George, E.F., M.A. Hall, G.J. De Klerk. 2007. Plant Propagation by In Vitro Culture. 3rd edition. Vol 1. The Backgroud. Exegetic. Basingtone, UK.

Latip, M.A., R. Datin, Z.A. Murdad, Aziz, 1. Ting L, HuiL, Malar, Govindasamy, R. Ripin. 2010. Effects of $\mathrm{N}^{6}$ benzyladenine and thidiazuron on proliferation of Phalaenopsis gigantea protocorms. Asia Pacific. J. Mol. Biol. Biotechnol. 18(1): 217-220.

Ling, L.F., S. Subramaniam. 2007. Biochemichal analyses of Phalaenopsis violacea orchids. Asian J. of Biochem. 2(4): 237-246.

Macdonald, B. 2002. Practical Woody Plant Propagation for Nursery Growers. Timber Pr. Inc. Portland. Oregon, US.

Matulata, A.V. 2003. Substitusi media MS dengan air kelapa dan Gandasil D pada kultur jaringan krisan. Eugenia 9(4): 203-211.

Niedz, R.P., T.J. Evens. 2007. Regulating plant in vitro growth by mineral nutrition. In Vitro Cell. Dev. Biol. Plant Vol. 43: 370-381.

Niknejad, A. 2009. Determination of genetic relationships among Phalaenopsis spp. using random amplified polymorphic DNA and in vitro propagation of Phalaenopsis gigantea [tesis]. Universiti Putra Malaysia. Kuala Lumpur, Malaysia.

Park, S.Y., H.N. Murthy, K.Y. Paek. 2002. Rapid propagation of Phalaenopsis from floral stalk derived leaves. In Vitro Cell. Dev. Biol. Plant Vol.38. 
Puspitaningtyas, D.M., S. Mursidawati, S. Wijayanti. 2006. Studi fertilitas Paraphalaenopsis serpetilingua J. J. Smith. Biodiversitas 7(3): 237-241.

Rachmatullah. 2009. Penggunaan hyponex dan bubur papaya dalam pembesaran planlet anggrek Dendrobium "Kanayao" secara in vitro dan perlakuan media aklimatisasi. Skripsi. Institut Pertanian Bogor. Bogor, Indonesia.

Rukmana, R. 2000. Budidaya Anggrek Bulan. Kanisius. Yogyakarta, Indonesia.

Sari, A.G., D. Hapsoro, S. Ramadiana. 2009. Pengaruh jenis media dasar $1 / 2$ MS dan Growmore dan pemberian pepton terhadap perkecambahan biji anggrek Dendrobium in vitro. Kumpulan
Abstrak Jurusan Budidaya Pertanian. Unila. Lampung, Indonesia.

Shintiavira, H., M. Soedarjo, Suryawati, B. Winarto. 2012. Studi pengaruh substitusi hara makro dan mikro media MS dengan pupuk majemuk dalam kultur in vitro krisan. J. Hort. 21(4): 334-341.

Sukma, D., A. Setiawati. 2010. Pengaruh waktu dan frekuensi aplikasi pupuk daun terhadap pertumbuhan dan pembungaan anggrek Dendrobium 'Tong Chai Gold'. J. Hort. Indonesia. 1(2): 96-103.

Supari. 1999. Tuntunan Membangun Agribisnis. Gramedia. Jakarta, Indonesia. 